\title{
Response of stream ecosystem structure to heavy metal pollution: context-dependency of top-down control by fish
}

\author{
Francesc Rubio-Gracia ${ }^{1}$ - María Argudo ${ }^{1}$ - Lluís Zamora ${ }^{1}$ - William H. Clements ${ }^{2}$ - Anna Vila-Gispert ${ }^{1}$. \\ Frederic Casals ${ }^{3,4} \cdot$ Helena Guasch ${ }^{1,5}$
}

Received: 17 November 2020 / Accepted: 17 January 2022 / Published online: 1 February 2022

(c) The Author(s) 2022

\begin{abstract}
The stress-gradient hypothesis predicts that biotic interactions within food webs are context dependent, since environmental stressors can attenuate consumer-prey interactions. Yet, how heavy metal pollution influences the impacts of predatory fish on ecosystem structure is unknown. This study was conducted in the Osor stream (Spain), which features a metal (mainly Zn) pollution gradient. We aimed to determine how the responses of benthic communities to the presence and absence of predatory fish interact with environmental stress and to test whether the top-down control of top predators is context dependent. To address these questions, periphyton biomass and macroinvertebrate densities were determined throughout an exclosure/ enclosure mesocosm experiment using the Mediterranean barbel (Barbus meridionalis) as a top predator. The monitoring study showed that metal accumulation in periphyton and macroinvertebrates reflected patterns observed in water. The mesocosm study showed that fish predation effects on larval chironomids were not context-dependent and that periphyton biomass was markedly lower in the presence of fish regardless of metal pollution levels. This strong top-down control on periphytic algae was attributed to the foraging behaviour of fish causing bioturbation. In contrast, the top predator removal revealed grazer-periphyton interactions, which were mediated by heavy metal pollution. That is, periphyton benefitted from a lower grazing pressure in the metal-polluted sites. Together, our results suggest that the top-down control by fishes depends more on functional traits (e.g. feeding behaviour) than on feeding guild, and demonstrate the capacity of top predators to modify anthropogenic stressor effects on stream food-web structure.
\end{abstract}

Keywords Barbus meridionalis · Trophic cascades · Biotic interactions · Grazing pressure $\cdot$ Macroinvertebrates · Periphyton biomass

Francesc Rubio-Gracia

francescmanel.rubio@udg.edu

1 GRECO, Institute of Aquatic Ecology, University of Girona, 17003 Girona, Catalonia, Spain

2 Department of Fish, Wildlife and Conservation Biology, Colorado State University, 80523 Fort Collins, USA

3 Department of Animal Science, University of Lleida, 25198 Lleida, Catalonia, Spain

4 Forest Science and Technology Centre of Catalonia-CTFC, 25280 Solsona, Catalonia, Spain

5 Integrative Freshwater Ecology Group, Centre d'Estudis Avançats de Blanes, CSIC, 17300 Blanes, Catalonia, Spain

\section{Introduction}

Chemical pollution represents one of the major threats to ecosystem integrity and biodiversity in running waters (Allan and Flecker 1993). The occurrence of metals in fluvial ecosystems is commonly due to urban and mining activities (Geist 2011). Heavy metal pollution can produce adverse effects on algal periphyton biomass, taxa richness and photosynthetic efficiency (Hill et al. 2000; Morin et al. 2008; Corcoll et al. 2012; Bonet et al. 2013), The diversity, taxa richness and abundance of benthic invertebrates are also affected by metal pollution (Clements et al. 2000; Maret et al. 2003; Smolders et al. 2003; Iwasaki et al. 2009). Moreover, aquatic organisms can accumulate metals by direct absorption through water and/or by feeding, depending on metal species and their concentrations in the environment (Clements and Rees 1997; Farag et al. 1998). 
Because periphyton readily bioaccumulates metals and is the primary food resource for invertebrates that scrape mineral and organic surfaces (Farag et al. 1998; Goodyear and McNeill 1999), it represents a potential link in the transfer of metals to higher trophic levels (Guasch et al. 2016; Bonnineau et al. 2020).

The co-occurrence of contaminants with other anthropogenic stressors, such as hydrological alterations that cause water stress, is common in freshwater ecosystems (Ormerod et al. 2010). It has been shown that water diversion exacerbates the ecological impacts of metal pollution (Guasch et al. 2009, 2010; Arenas-Sánchez et al. 2016), as the capacity to dilute pollutants is compromised (Petrovic et al. 2011). Moreover, recent studies have yielded invaluable information on the direct and combined effects of chemical pollution and water stress on target organisms, such as periphyton and invertebrates (Ponsatí et al. 2016; Sabater et al. 2016; Kalogianni et al. 2017; Karaouzas et al. 2018). However, biotic interactions within food webs can modify stressor effects, transfer stressor effects to distant groups of organisms, and create new stressor interactions (Bruder et al. 2019). To date, several field and theoretical studies have demonstrated contaminant-induced changes in either behaviour (Schmitz et al. 2004; Saaristo et al. 2018), competition or predation/grazing rate (Fleeger et al. 2003; Alexander et al. 2013; Rodrigues et al. 2018) that altered species abundances or community composition. As illustrated in Fig. 1, contaminants can have both direct and indirect effects across trophic levels (previously described by Clements and Rohr 2009). Therefore, accounting for biotic interactions within food webs can increase our mechanistic understanding of ecological responses to environmental stressors (Clements and Rohr 2009; Segner et al. 2014; Brooks and Crowe 2018; Bruder et al. 2019).

Community ecologists define trophic cascades as the effects of predators that propagate downward across trophic levels through indirect interactions (Wootton 1994; Polis et al. 2000; Ripple et al. 2016). Typically, the manipulation of the top trophic level (often extirpation) such as insectivorous fish or smaller carnivores (mesopredators) can result in trophic cascades affecting primary producers through consumptive- or density-mediated effects (e.g. Power 1990a; Flecker and Townsend 1994; Biggs et al. 2000; Rosenfeld 2000; Ritchie and Johnson 2009) and non-consumptive- or trait-mediated effects (e.g. Konishi et al. 2001; Moulton et al. 2004). However, not all food webs have a linear shape (Rodríguez-Lozano et al. 2015) and consumer effects are often context dependent (Holomuzki et al. 2010). One driver that may regulate trophic cascade strength within systems is environmental stress, which is well known to mediate biotic interactions (Menge and Sutherland 1987). In 1987, Menge and Sutherland developed the environmental stress model, in which top-down community regulation is predicted to (a)

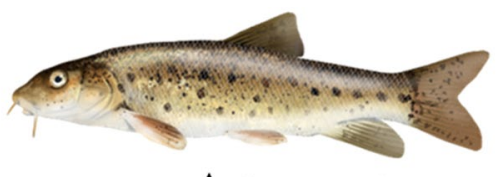

(b)

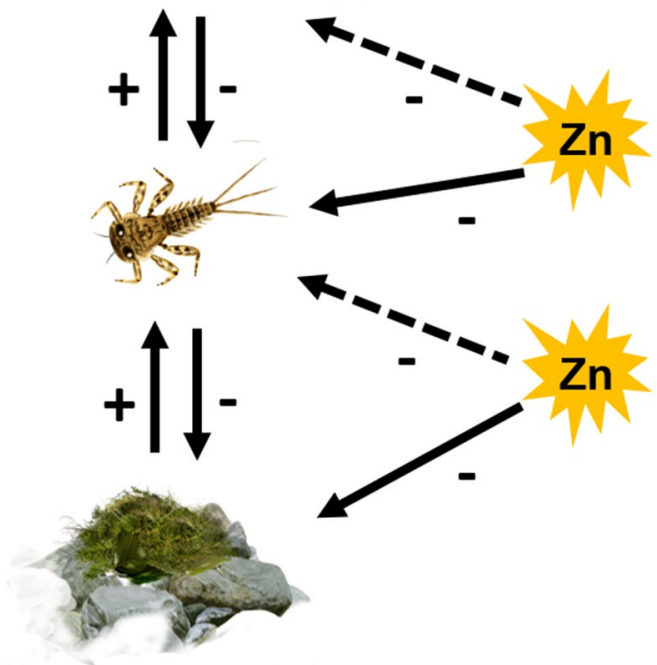

Fig. 1 A simplified representation of biotic interactions in a stream food web (with three trophic levels: a fish, b primary consumers and $\mathbf{c}$ primary producers) based on periphyton (benthic algae) with the presence of stressors (e.g. Zn contamination). Solid lines are direct effects; dashed lines represent indirect effects. The presence or absence of predatory fishes can result in cascading effects because of grazer-periphyton interactions. Positive and negative effects are signified by (+) and (-), respectively. Modified from: Clements and Rohr (2009)

dominate in non-impacted habitats, whereas environmental stressors can attenuate consumer-prey interactions (e.g. due to predator emigration) and thereby alter trophic cascades. Since Menge and Sutherland's work, a growing number of studies have focused on quantifying the strength of trophic cascades across environmental stress gradients, especially in salt marshes (e.g. Korpinen et al. 2007; Cheng and Grosholz 2016; McAfee and Bishop 2019), but with a limited number of studies performed in streams (e.g. Layer et al. 2010). Habitat complexity, resource subsidies, the type and intensity of environmental stress, predator behaviour and efficiency, and system productivity are known to influence interactions within food webs (Power 1992; Strong 1992; Brönmark et al. 1997; Borer et al. 2005; Leroux and Loreau 2008; Klemmer and Richardson 2013).

Previous studies focusing on the effects of metal pollution found that the relative importance of stonefly predation (Plecoptera: Perlidae) can be altered due to changes in prey immigration (Clements 1999) or in background prey density (Kiffney 1996). Yet, how metal pollution influences top-down control by fish remains largely unknown.

This study was conducted in the Osor stream (Catalonia, Spain). This stream features a metal pollution gradient 
Fig. 2 Map showing the locations of the five selected reaches along the Osor stream (NE Iberian Penisula, Ter river basin (shaded in dark grey); the watershed of the Osor stream is shaded in blue), and diagram of the experimental setup showing the size of the mesocosms (cages) and the two treatments established. With the exception of Upstream 1 (UP-1), the rest of stream reaches were affected by hydrological alteration (water diversion) and/or heavy metal pollution: Upstream 2 (UP-2), Mine (M), Downstream 1 (DM-1) and Downstream 2 (DM-2)

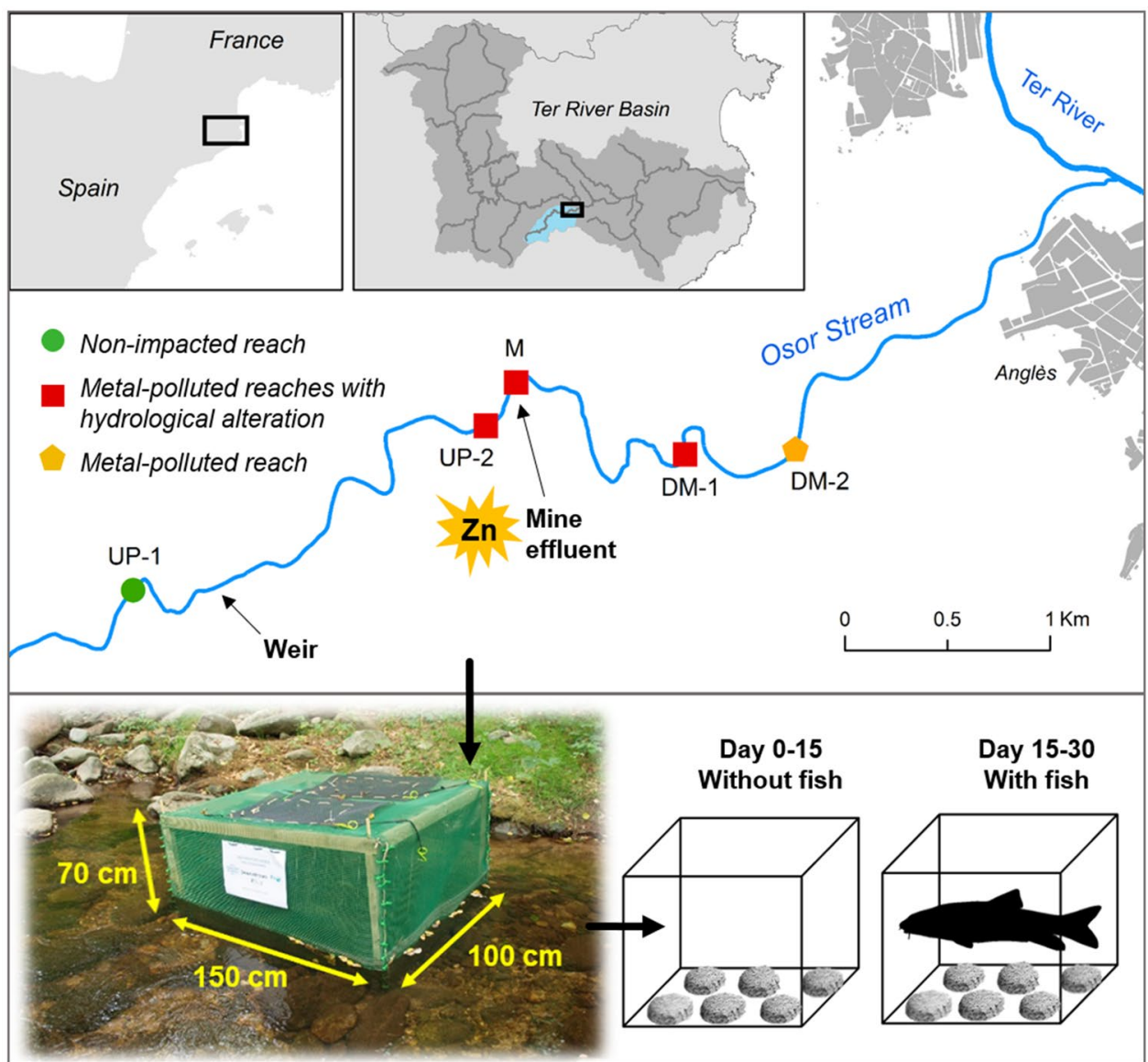

as a result of metal inputs from mine drainage and runoffs, and water diversion (Tlili et al. 2011; Corcoll et al. 2012; Bonet et al. 2013, 2014). This pollution gradient provides a unique opportunity for understanding how trophic relationships interact with environmental stress, and to test whether the ecological role of top predators in streams is context dependent. Therefore, we aimed to evaluate the responses of periphyton biomass and density of benthic macroinvertebrates to the presence and absence of a predatory fish along the metal pollution gradient. To address this, we used an insectivore benthic species (Mas-Martí et al. 2010; Rodríguez-Lozano et al. 2016b), the Mediterranean barbel (Barbus meridionalis), as a study case in a field exclosure/enclosure mesocosm experiment. We hypothesised that periphyton biomass and the density of macroinvertebrates would decline in the most polluted sites (Clements et al. 2000; Bonet et al. 2013). Moreover, macroinvertebrate communities are expected to be topdown controlled by $B$. meridionalis, as previous research has shown (Rodríguez-Lozano et al. 2015, 2016a); however, metal pollution can decouple species interactions, thereby affecting the strength of the top-down control (Kiffney 1996; Clements 1999).

\section{Methods}

\section{Study area}

This study was carried out in Osor stream, a second-order stream in the northeast of the Iberian Peninsula, Spain (Fig. 2). This stream is $28.5 \mathrm{~km}$ long, with a drainage area of $88 \mathrm{~km}^{2}$ and runs primarily through Guilleries Mountains until drains into the Ter River. It features moderately hard waters $\left(1 \mathrm{mM} \mathrm{Ca}^{2+}\right)$ and well-preserved riparian vegetation. However, several human-driven stressors such as hydrological alteration and metal pollution threaten the ecological integrity of the stream. This catchment is subjected to seasonal rainstorms during the autumn and spring, causing spates that increase stream base-flow; however, during the summer drought, stream discharge is substantially reduced. The presence of a diversion channel causes further flow reductions downstream (Bonet et al. 2013) and eventually causes streambed drying (personal observation). This stream also receives effluents and runoff from an inactive former mine that extracted spharelite $((\mathrm{Zn}, \mathrm{Fe}) \mathrm{S})$ and galena $(\mathrm{PbS})$. Dissolved concentrations of metals in water depend on season and stream discharge, with the highest concentrations coinciding with periods of summer drought (Bonet et al. 
2013). Zinc is one of the most abundant elements in the surroundings of the mine discharge (nearly $450 \mu \mathrm{g} \mathrm{Zn} \mathrm{L}^{-1}$ ), and concentrations often exceed the water quality standards stipulated by European and American legislation (Bonet et al. 2014).

Five sampling reaches were selected along a 5-km segment of the stream with the purpose of obtaining a metal pollution gradient (Fig. 2). These reaches were as follows: Upstream 1 (UP-1; the reference site), located at about $3.7 \mathrm{~km}$ distance away from the mine effluent and unaffected by water diversion; Upstream 2 (UP-2), located $100 \mathrm{~m}$ upstream of the most polluted reach and altered by the presence of a diversion channel for hydropower production; Mine (M), located just down the mine discharge and with the highest metal concentrations in water; Downstream 1 (DM-1), located at about $0.6 \mathrm{~km}$ downstream from the mine discharge and altered by water abstraction and diversion; and finally Downstream 2 (DM-2), located at $1.4 \mathrm{~km}$ downstream from the mine and considered partially recovered from the diverted flow.

Preliminary electrofishing with multiple passes (three pass depletion) and block nets indicated that the fish assemblage was largely dominated by the native Mediterranean barbel (Barbus meridionalis) and the invasive minnow (Phoxinus sp.). The mean densities (individuals $\mathrm{ha}^{-1}$ ) of Barbus meridionalis and Phoxinus sp. along the selected reaches were, respectively, the following: 2164 and 2305 in UP-1; 1986 and 2416 in UP-2; 1362 and 3715 in M; 2419 and 3523 in DM-1; and 4115 and 1652 in DM-2.

\section{Description of water chemistry, periphyton and macroinvertebrates}

In summer 2017, several samplings were conducted within each study reach to describe the direct effects of environmental stress on biological communities (periphyton and benthic macroinvertebrates). A field mesocosm experiment was performed in parallel to test the influence of fish on the reported responses (described in "Exclosure/enclosure mesocosm experiment").

\section{Water chemistry}

Physicochemical parameters were measured in-situ using a multi-parametric probe (WTW Meters, Weilheim, Germany). Water samples were taken for nutrient and dissolved metal analysis. Phosphate and ammonium concentrations were measured colorimetrically (Murphy and Riley 1962; Reardon et al. 1966) using a spectrophotometer (Shimadzu UV-1800). Analytical methods for trace metal concentrations are described in "Metal analysis".

\section{Periphyton sampling}

Cobbles were randomly collected in the field and were thoroughly scraped with cell scrapers, rinsed with water and filtered onto $\mathrm{GF} / \mathrm{F}$ Whatman filters $(0.7 \mu \mathrm{m}$-pore size $)$. In the laboratory, samples were stored frozen at $-20{ }^{\circ} \mathrm{C}$ and aliquots of these samples were used to estimate chlorophyll$a$ concentration and total organic biomass or ash-free dry weight (AFDW). Chlorophyll- $a$ was measured after extracting in $10 \mathrm{~mL}$ of $90 \%$ acetone for $24 \mathrm{~h}$ in the dark at $4{ }^{\circ} \mathrm{C}$ and sonicating for $2 \mathrm{~min}$ at $40 \mathrm{kHz}$. Chlorophyll- $a$ concentration was determined spectrophotometrically (Jeffrey and Humphrey 1975). Ash-free dry weight (AFDW) biomass was determined following standard methods (Steinman et al. 2007): GF/F Whatman filters $(0.7 \mu \mathrm{m}$-pore size) were dried at $50{ }^{\circ} \mathrm{C}$ for $48 \mathrm{~h}$, weighed to determine dry weigh, combusted at $450{ }^{\circ} \mathrm{C}$ for $4 \mathrm{~h}$ to determine mineral content, and reweighed to determine the ash-free dry weight (AFDW); estimated as the difference between weight measurements. Cobble dimensions were used to standardise periphyton biomass per surface area ( $\mu \mathrm{g}$ chlorophyll $-a \mathrm{~cm}^{-2}$ and $\mathrm{mg}$ AFDW $\mathrm{cm}^{-2}$ ). Samples of periphyton were also taken (one sample per reach) for analysis of metal bioaccumulation (see metal analysis section) and were stored frozen at $-20{ }^{\circ} \mathrm{C}$. We calculated the bioconcentration factor (BCF) as the ratio of metal concentration in periphyton to that in water, considering that metal toxicity for organisms depend on bioavailability in the abiotic medium and the capacity of organisms to accumulate metals.

\section{Macroinvertebrates sampling}

Benthic macroinvertebrates were collected from undisturbed shallow runs and riffles using a Surber sampler $(20 \times 20 \mathrm{~cm}$ and $250 \mu \mathrm{m}$ mesh net) and stored in plastic bottles containing $70 \%$ ethanol. We used eight replicates for each sampling site because this amount of sampling effort is considered sufficient to characterise macroinvertebrate communities (Gartzia De Bikuña et al. 2015). In the laboratory, benthic macroinvertebrates were counted and identified to family under a dissecting microscope. Families of mayflies (Ephemeroptera), stoneflies (Plecoptera) and caddisflies (Trichoptera) were grouped as EPT taxa, whereas families of dragonflies (Odonata), beetles (Coleoptera) and true bugs (Hemiptera) were grouped as OCH taxa. Following Tachet et al. (2000), macroinvertebrate families were assigned to functional feeding groups (FFG): grazers, shredders, collector-gatherers (also termed deposit-feeders), collector-filterers and predators. For taxa assigned to multiple FFGs, densities were divided evenly into each applicable FFG (estimated as a percentage). Parasites were omitted from the analysis. After identification, samples were dried at $60{ }^{\circ} \mathrm{C}$ until constant mass and weighed $( \pm 0.1 \mathrm{mg})$ to obtain the total dry mass 
(DM). For snails, shells were removed and the remaining body parts were dried and weighed. Density of macroinvertebrates and total dry mass (all individuals pooled) were standardised by surface area sampled (individuals $\mathrm{m}^{-2}$ and $\mathrm{g} \mathrm{DM} \mathrm{m}^{-2}$ ).

A sample of four representative macroinvertebrate families (Leuctridae, Hydropsychidae, Gomphidae and Lymnaidae) was also used for analysis of metal bioaccumulation. In total, we collected a minimum of 50 individuals per family from each reach. Samples included a mixture of taxa within each family to avoid interspecific variability in metal accumulation and to obtain sufficient biomass for metal analysis (Kotalik and Clements 2019). Macroinvertebrates were stored in plastic vials and frozen at $-80{ }^{\circ} \mathrm{C}$ until metal analysis (see metal analysis section). A bioaccumulation factor (BAF) was calculated as the ratio of metal concentration in macroinvertebrates to that in periphyton.

\section{Exclosure/enclosure mesocosm experiment}

Following previous work (Rubio-Gracia et al. 2017), we set up a mesocosm experiment that allowed us to control the presence or absence of fish and quantify treatment effects on trophic levels. The experiment was conducted for 4 weeks between June and July 2017. We established two treatments (exclosure and enclosure) with a duration of 2 weeks each one and replicated three times in each study reach (Fig. 2). Treatment effects were evaluated following a before-andafter design: (1) first, cages without fish were used to simulate the lack of fish predation (exclosure experiment); and (2) afterwards, 6 Barbus meridionalis were placed into the same cages (enclosure experiment), simulating the high fish density (around 6 individuals per $\mathrm{m}^{2}$ ) that are typical of well-preserved rivers or in isolated pools when some Mediterranean-climate streams dry down (Rubio-Gracia et al. 2017). The 90 barbels used in this experiment (range fork length, FL $=84-115 \mathrm{~mm}$ ) were previously caught by electrofishing (LR-24 Smith-Root Ltd. 120 V DC-0.6 A) from the reference site (Upstream 1) and transferred to downstream reaches. Thus, we avoided the potential harmful effects of long-term metal bioaccumulation on fish. Mesocosms $(150 \times 100 \times 70 \mathrm{~cm})$ consisted of four-sided cages made of high-density polyethylene (HDPE), which were held up by a wooden structure, and covered by a mesh of HDPE on the top (Fig. 2), which prevented predation of fish by aquatic birds and other animals. Cages were separated a minimum of $10 \mathrm{~m}$ to avoid interference. The mesh size of cages $(4.5 \mathrm{~mm}$ pore size) retained or excluded fish but allowed macroinvertebrate movement and algal colonization, and also light penetration through the cover material (Argudo 2021), thereby minimising the impact of our experimental design on trophic interactions. To simulate natural conditions and promote rapid colonization by stream communities, cage bottoms were filled with cobbles taken from the same sampling point. During the experiment, the cages were inspected every day to remove debris that accumulated outside of the cages due to stream current. The substrate used for sampling periphyton and macroinvertebrate was returned to the stream channel to avoid repetition of sample units.

Surveys were conducted after 1 and 2 weeks over the course of each treatment period. On each sampling date, three randomly selected cobbles were removed by hand and their surfaces carefully rubbed to dislodge any aquatic macroinvertebrates, while one random boulder was used to sample periphytic algae. We essentially followed the same methodology described above for the determination of macroinvertebrate densities, chlorophyll- $a$ concentration and AFDW biomass.

\section{Metal analysis}

Metal analyses included water, periphyton and macroinvertebrate samples. Water samples were filtered onto Whatman nylon filters $(0.2 \mu \mathrm{m}$-pore size $)$ and acidified with $1 \% \mathrm{HNO}_{3}$ (65\% suprapure, Merck). Dissolved metals were determined by inductively coupled plasma mass spectroscopy (ICP-MS 7500c Agilent Technologies). Periphyton and macroinvertebrate samples were processed and analysed for $\mathrm{Zn}, \mathrm{Mn}, \mathrm{Fe}$, $\mathrm{Cr}, \mathrm{Cd}, \mathrm{Cu}$ and $\mathrm{Pb}$. All samples were lyophilized, weighted with an analytical balance (Menttler-Toledo AX205), and digested in nitric acid ( $4 \mathrm{~mL} \mathrm{HNO}_{3}, 65 \%$ suprapure, Merck) and hydrogen peroxide ( $1 \mathrm{~mL} \mathrm{H}_{2} \mathrm{O}_{2}, 30 \%$ suprapure, Merck) in a high-performance microwave digestion unit (Milestone, Ethos Sel). Digested samples were analysed by inductively coupled plasma mass spectroscopy (ICP-MS 7500c Agilent Technologies) $\mathrm{Zn}$ concentrations in macroinvertebrates were analysed by inductively coupled plasma mass (ICPOES 5100 Agilent Technologies). Analytical accuracy was determined using certified reference material of the Joint Research Centre (European Commission), i.e., standard trace elements in fish muscle tissue (ERM-BB422).

\section{Data analysis}

Statistical analyses were performed in the R software environment (R Development Core Team 2018). Residual plots of response variables were used to test for the homoscedasticity and normality of residuals. Generally, response variables of the biomonitoring study followed a normal distribution after applying the square root transformation. If parametric assumptions were met, analysis of variance (ANOVA) was used to test for differences in response variables among stream reaches. If not, non-parametric test (Kruskal-Wallis test) was then used as an alternative to the one-way ANOVA. Tukey and Dunn's tests of multiple comparisons were subsequently used to elucidate significant 
differences among stream reaches. Linear regressions were applied to predict the relationship between metal concentrations in periphyton and macroinvertebrate families, while intercepts of parallel regression lines were compared using analysis of covariance (ANCOVA). Further, we performed pairwise comparisons of adjusted means (Bonferroni method) using the 'emmeans' package in R to identify which macroinvertebrate families were different. Regarding the experimental study, macroinvertebrate and periphyton data were better transformed into normality and homogeneity using the Box-Cox power transformation (Box and Cox 1964). The optimal exponent (lambda) for each dependent variable was estimated using maximum likelihood estimation through regression models with 'Reach' and 'Treatment' as predictors. Since the Box-Cox Power transformation only works if all the values are greater than zero, a fixed value ( $\alpha=0.5$ ) was added to dependent variables before applying the transformation. Due to the low densities of some macroinvertebrate orders in cages, we used the density of EPT and OCH metrics to increase the statistical power of subsequent linear models. The transformed responses were then fit using linear mixed models (the 'lmer' function of the 'Ime4' package in R; Bates et al. 2015) to investigate the interaction effects between 'Reach' and 'Treatment' as fixed factors, while 'Time' and 'Replicate' were treated as random factors. We tested the random-effect terms in the model using the 'ranova' function of the 'ImerTest' package in R (Kuznetsova et al. 2017). Finally, we calculated $P$ values and the marginal and conditional $R^{2}$ with the 'ImerTest' and 'MuMIn' R-packages (Nakagawa and Schielzeth 2013), respectively. The marginal $R^{2}$ describes the variance explained by the fixed effects, while the conditional $R^{2}$ describes the variance jointly explained by the fixed and the random effects.

\section{Results}

\section{Characterization of water chemistry and stream communities}

Physicochemical parameters of the sampling reaches are presented in Table 1. Water discharge was markedly lower in the reach located just downstream the diversion channel, (Upstream 2), and there was a progressive recovery of stream discharge in downstream reaches. We also found that nutrient concentrations (phosphate and nitrate) were slightly higher in upstream reaches than in the Mine and downstream reaches. Metals such as $\mathrm{Zn}, \mathrm{Mn}$ and Fe largely showed the highest concentrations in water (Table 1) and in periphyton (Table 2). There were no significant differences in total biomass (AFDW) and chlorophyll- $a$ concentration among

Table 1 Physical and chemical features of water, and community structure of periphyton and macroinvertebrates along the Osor stream

\begin{tabular}{|c|c|c|c|c|c|}
\hline & UP-1 & UP-2 & M & DM-1 & DM-2 \\
\hline Water discharge $\left(\mathrm{m}^{3} \mathrm{~s}^{-1}\right)$ & $0.12 \pm 0.02$ & $0.05 \pm 0.01$ & $0.08 \pm 0.03$ & $0.06 \pm 0.01$ & $0.09 \pm 0.01$ \\
\hline Temperature $\left({ }^{\circ} \mathrm{C}\right)$ & $18.9 \pm 1.5$ & $20.14 \pm 1.6$ & $20.96 \pm 1.7$ & $20 \pm 1.2$ & $20.76 \pm 1.0$ \\
\hline Oxygen $\left(\mathrm{mg} \mathrm{L}^{-1}\right)$ & $8.37 \pm 0.46$ & $7.75 \pm 0.29$ & $8.09 \pm 0.24$ & $8.18 \pm 0.1$ & $8.18 \pm 0.28$ \\
\hline $\mathrm{pH}$ & $8.34 \pm 0.08$ & $8.14 \pm 0.06$ & $8.19 \pm 0.07$ & $8.24 \pm 0.16$ & $7.86 \pm 0.13$ \\
\hline Cond $\left(\mu \mathrm{S} \mathrm{cm}^{-1}\right)$ & $373 \pm 41$ & $416 \pm 82$ & $517 \pm 25$ & $484 \pm 18$ & $463 \pm 30$ \\
\hline $\mathrm{PO}_{4}^{3-}\left(\mathrm{mg} \mathrm{L}^{-1}\right)$ & $0.53 \pm 0.11$ & $0.42 \pm 0.04$ & $0.30 \pm 0.03$ & $0.36 \pm 0.11$ & $0.42 \pm 0.09$ \\
\hline $\mathrm{NH}_{4}^{+}\left(\mu \mathrm{g} \mathrm{L}^{-1}\right)$ & $27.42 \pm 17.01$ & $33.54 \pm 14.21$ & $48.56 \pm 44.15$ & $25.52 \pm 6.88$ & $28.17 \pm 3.91$ \\
\hline $\mathrm{NO}_{3}^{-}\left(\mathrm{mg} \mathrm{L}^{-1}\right)$ & $2.59 \pm 0.74$ & $1.22 \pm 0.29$ & $1.04 \pm 0.36$ & $1.44 \pm 0.58$ & $1.52 \pm 0.46$ \\
\hline $\mathrm{Zn}\left(\mu \mathrm{g} \mathrm{L}^{-1}\right)$ & $21.02 \pm 20.05$ & $25.41 \pm 10.92$ & $349.0 \pm 121.69$ & $224.98 \pm 93.48$ & $84.61 \pm 36.78$ \\
\hline $\operatorname{Mn}\left(\mu \mathrm{g} \mathrm{L}^{-1}\right)$ & $20.82 \pm 7.79$ & $25.25 \pm 8.06$ & $143.38 \pm 34.78$ & $48.36 \pm 14.18$ & $24.68 \pm 10.80$ \\
\hline $\mathrm{Fe}\left(\mu \mathrm{g} \mathrm{L}{ }^{-1}\right)$ & $132.94 \pm 60.89$ & $128.20 \pm 152.15$ & $96.39 \pm 23.45$ & $91.72 \pm 39.96$ & $47.16 \pm 36.07$ \\
\hline $\mathrm{Ni}\left(\mu \mathrm{g} \mathrm{L}^{-1}\right)$ & $0.83 \pm 0.70$ & $0.43 \pm 0.08$ & $3.34 \pm 1.09$ & $2.22 \pm 1.26$ & $1.55 \pm 0.99$ \\
\hline \multicolumn{6}{|l|}{ Periphyton } \\
\hline Chlorophyll- $a\left(\mu \mathrm{g} \mathrm{cm}^{-2}\right)$ & $1.08 \pm 0.81$ & $3.36 \pm 2.73$ & $2.70 \pm 2.26$ & $7.21 \pm 7.06$ & $7.02 \pm 8$ \\
\hline $\operatorname{AFDW}\left(\mathrm{mg} \mathrm{cm}^{-2}\right)$ & $0.84 \pm 0.62$ & $0.98 \pm 0.26$ & $0.58 \pm 0.12$ & $1.04 \pm 0.58$ & $0.97 \pm 0.53$ \\
\hline \multicolumn{6}{|l|}{ Macroinvertebrates } \\
\hline Family richness & $23.33 \pm 3.09$ & $21.00 \pm 1.63$ & $16.67 \pm 1.70$ & $20.00 \pm 1.41$ & $21.33 \pm 3.09$ \\
\hline Total density (individuals $\mathrm{m}^{-2}$ ) & $1000.08 \pm 191.57^{\mathrm{a}, \mathrm{b}}$ & $1147 \pm 267.22^{b}$ & $520.06 \pm 63.05^{\mathrm{a}}$ & $580.70 \pm 99.15^{\mathrm{a}}$ & $835.14 \pm 188.34^{\mathrm{a}, \mathrm{b}}$ \\
\hline Total dry mass $\left(\mathrm{g} \mathrm{DM} \mathrm{m}^{-2}\right)$ & $0.41 \pm 0.08^{\mathrm{a}, \mathrm{b}}$ & $0.73 \pm 0.10^{\mathrm{b}}$ & $0.21 \pm 0.08^{\mathrm{a}}$ & $0.30 \pm 0.10^{\mathrm{a}}$ & $0.44 \pm 0.09^{\mathrm{a}, \mathrm{b}}$ \\
\hline
\end{tabular}

Stream reaches are: Upstream 1 (UP-1; the reference site), Upstream 2 (UP-2), Mine (M), Downstream 1 (DM-1) and Downstream 2 (DM-2). Nutrient concentrations were obtained from Argudo (2021). Data are shown as average \pm standard deviation $(N=3)$. Significant differences in variables of periphyton and macroinvertebrate among the stream reaches are represented by different lowercase letters (Tukey's test, $P<0.05$ ) 


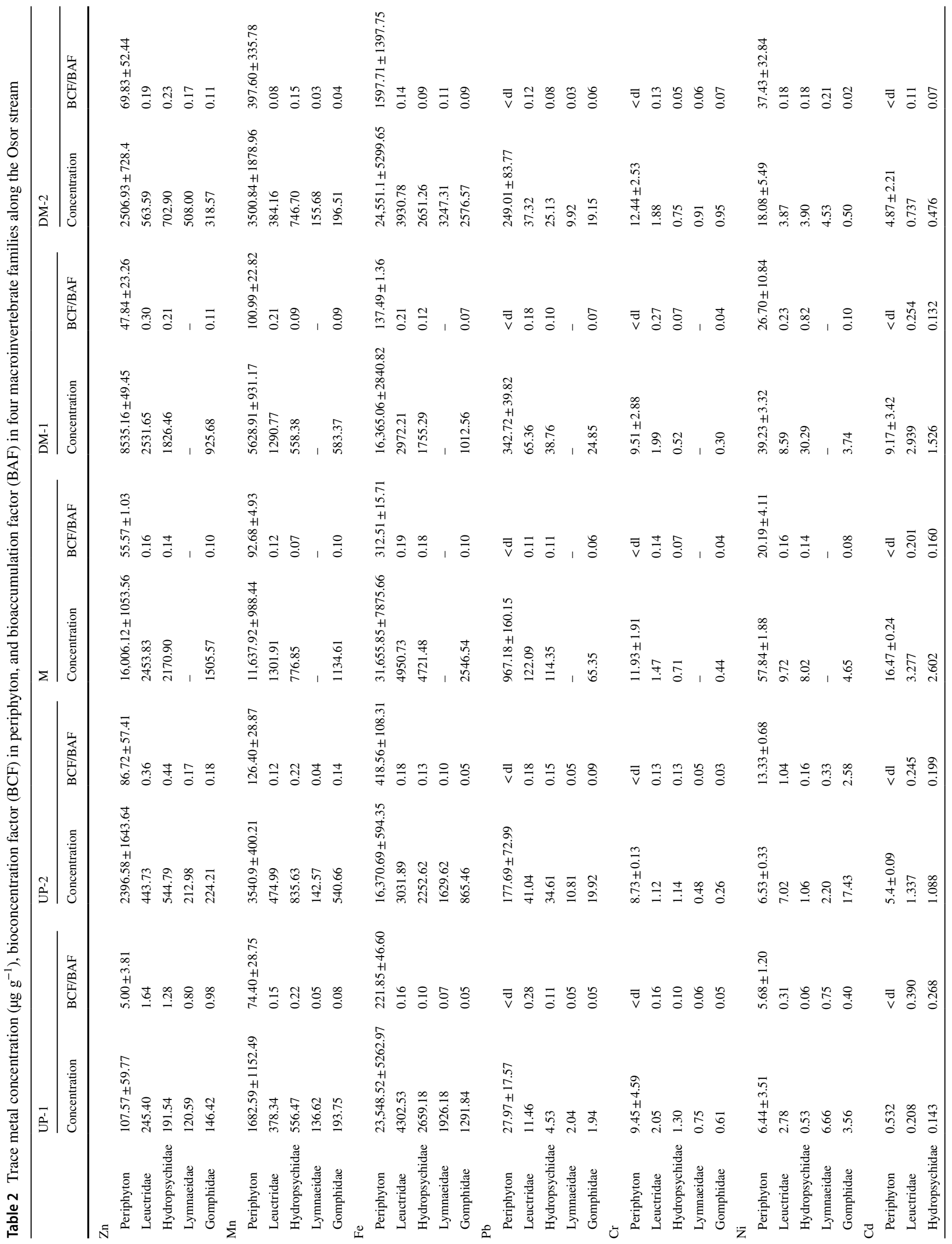




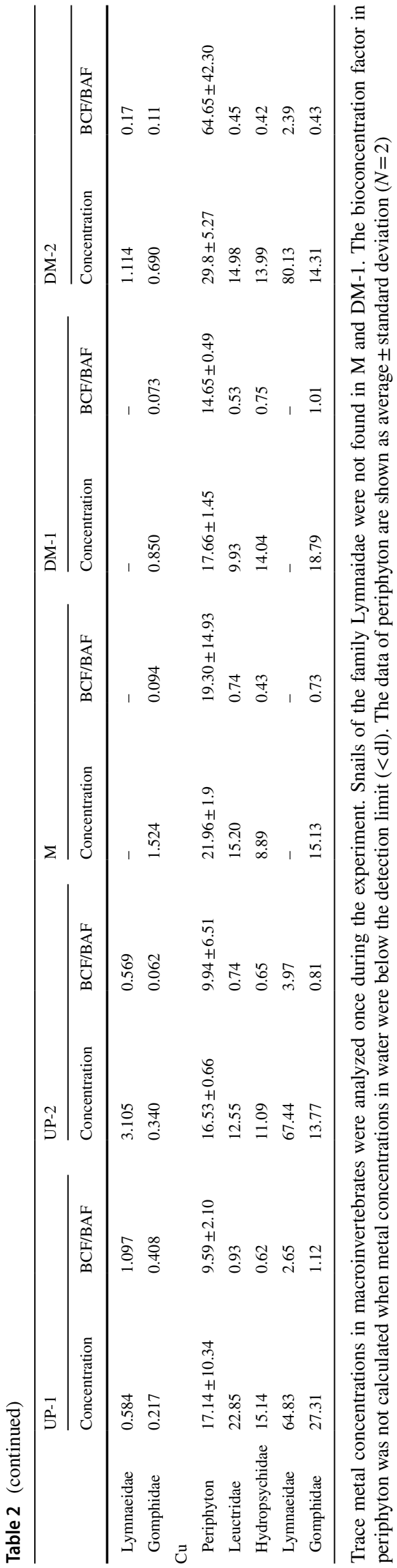

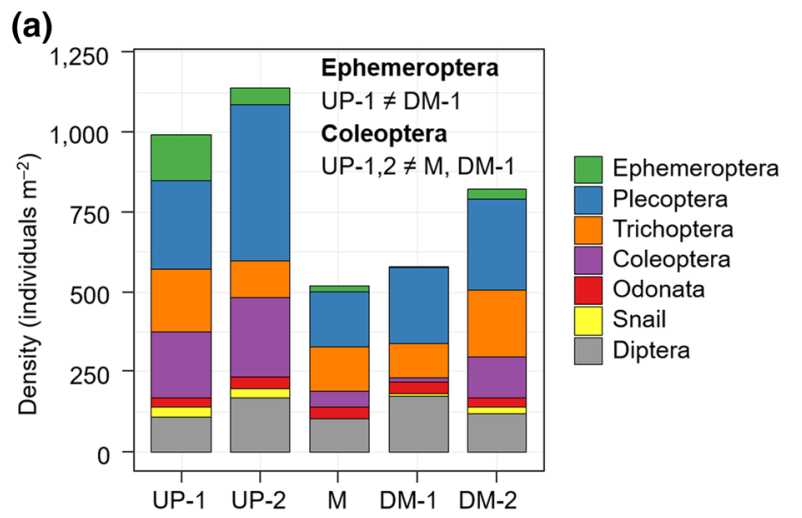

(b)

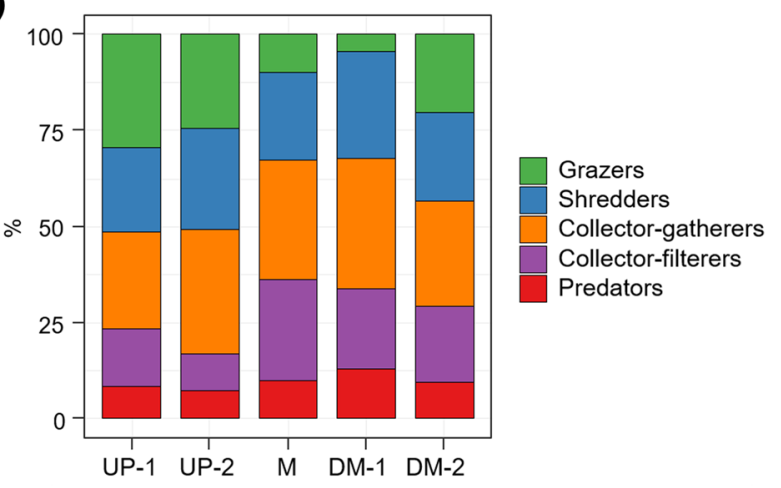

Fig. 3 Density of benthic macroinvertebrates (a) and proportion of the different feeding groups (b) along the Osor stream. Stream reaches are: Upstream 1 (UP-1), Upstream 2 (UP-2), Mine (M), Downstream 1 (DM-1) and Downstream 2 (DM-2). Dunn and Tukey's tests showed significant differences in the density of Ephemeroptera and Coleoptera orders among the reaches, respectively $(P<0.05)$

reaches (Table 1; Kruskal-Wallis test, $P>0.05$ ). Periphyton showed the highest concentrations of heavy metals in Mine reach, followed by Downstream 1 and 2, Upstream 2 and finally Upstream 1 (Table 2).

In total, 49 families of macroinvertebrates were identified in Osor stream. Family richness was similar among reaches (Table 1); however, we found significant differences in total macroinvertebrate density (ANOVA; $F_{4,10}=5.43$, $P=0.014)$ and total dry mass $\left(F_{4,10}=8.50, P=0.003\right)$ between Upstream 2 and both Mine and Downstream 1 (Table 1; Fig. 3a). In the least polluted reaches, the macroinvertebrate community was dominated by Plecoptera (mostly Leuctridae), followed by Coleoptera (mostly Elmidae), Trichoptera (mostly Hydropsychidae, Polycentropodidae and Philopotamidae), and nematoceran Diptera (mostly Chironomidae). In contrast, Ephemeroptera (mostly Caenidae, Ephemerillidae and Baetidae), Odonata (mostly Gomphidae) and snails (mostly Ancylidae and Lymnaeidae) were generally less abundant downstream, especially in the most polluted reaches (Fig. 3a). There were also very few annelids (Oligochaeta) in the stream $(<15$ 
individuals $\mathrm{m}^{-2}$ ). We found that densities of Coleoptera were significantly lower in Mine and Downstream 1 (ANOVA; $\left.F_{4,10}=16.43, P<0.001\right)$, and densities of Ephemeroptera were significantly lower in Downstream 1 (Kruskal-Wallis test; chi-squared $=11.31, d f=4, P=0.02$ ). Overall density of grazers was significantly lower in Mine and Downstream 1 (ANOVA; $F_{4,10}=19.56, P<0.001$ ) so that the density of this functional feeding group accounted for a small proportion of the total macroinvertebrate density in those reaches (Fig. 3b).

As with periphyton, macroinvertebrates mostly bioaccumulated $\mathrm{Zn}, \mathrm{Mn}$ and $\mathrm{Fe}$, and it was also found that periphyton showed much greater metal concentrations compared to macroinvertebrates (Table 2). An increase in concentration from periphyton to grazers of the family Lymnaeidae $(\mathrm{BAF}>1)$ was only observed for $\mathrm{Cu}$ in all reaches where these snails were found (Table 2). The relationship of metal concentrations between periphyton and macroinvertebrates was significant for several metals ( $\mathrm{Zn}, \mathrm{Pb}, \mathrm{Cr}$ and $\mathrm{Cd}$ ) in two or more macroinvertebrate families (Table S1). Therefore, this shows that periphyton and macroinvertebrates, although having different metal loads, followed similar patterns of metal bioconcentration and bioaccumulation across the pollution gradient. Moreover, we found differences in bioaccumulation of $\mathrm{Zn}$ (ANCOVA, $F_{3,13}=6.15, P=0.008$ ), $\mathrm{Pb}$ $\left(F_{3,13}=18.64, P<0.001\right)$ and $\mathrm{Cd}\left(F_{2,11}=4.88, P=0.03\right)$ among the macroinvertebrate families (i.e. regression models had significantly different intercepts). Concentrations of $\mathrm{Zn}$ and $\mathrm{Pb}$ in invertebrates increased along the gradient Leuctridae $=$ Hydropsychidae $>$ Gomphidae (Fig. 4a, b), at similar periphyton metal concentrations; however, concentrations of $\mathrm{Cd}$ in Leuctridae were higher than in Gomphidae, at similar periphyton Cd concentrations (Fig. 4c). Lymnaeidae family was not included in the ANCOVA models because of the absence of this taxon in the most-polluted sites.

\section{Fish treatment effects}

Although three barbels died at the end of the enclosure experiment in Upstream 2 and Mine (2 and 1 fish, respectively), it is unlikely that this small change in fish density affected our results. In total, 34 different macroinvertebrate taxa were found during the exclosure/enclosure mesocosm experiment, including 12 caddisflies (Trichoptera); 6 dipterans (Diptera); 5 mayflies (Ephemeroptera); 4 dragonflies or damselflies (Odonata); 3 snails; 2 beetles (Coleoptera), and 1 stonefly (Plecoptera) and annelid (Oligochaete). Linear mixed models showed that variation in macroinvertebrate densities and periphyton biomass were mostly explained by 'Reach' and 'Treatment' effects (i.e. absence/presence of fish) (Table 3) because the effects of 'Time' and 'Replicate' were not significant for any of the models tested $(P>0.05)$.
- Hydropsychidae $\square$ Leuctridae $\Delta$ Gomphidae $\bullet$ Lymnaeidae
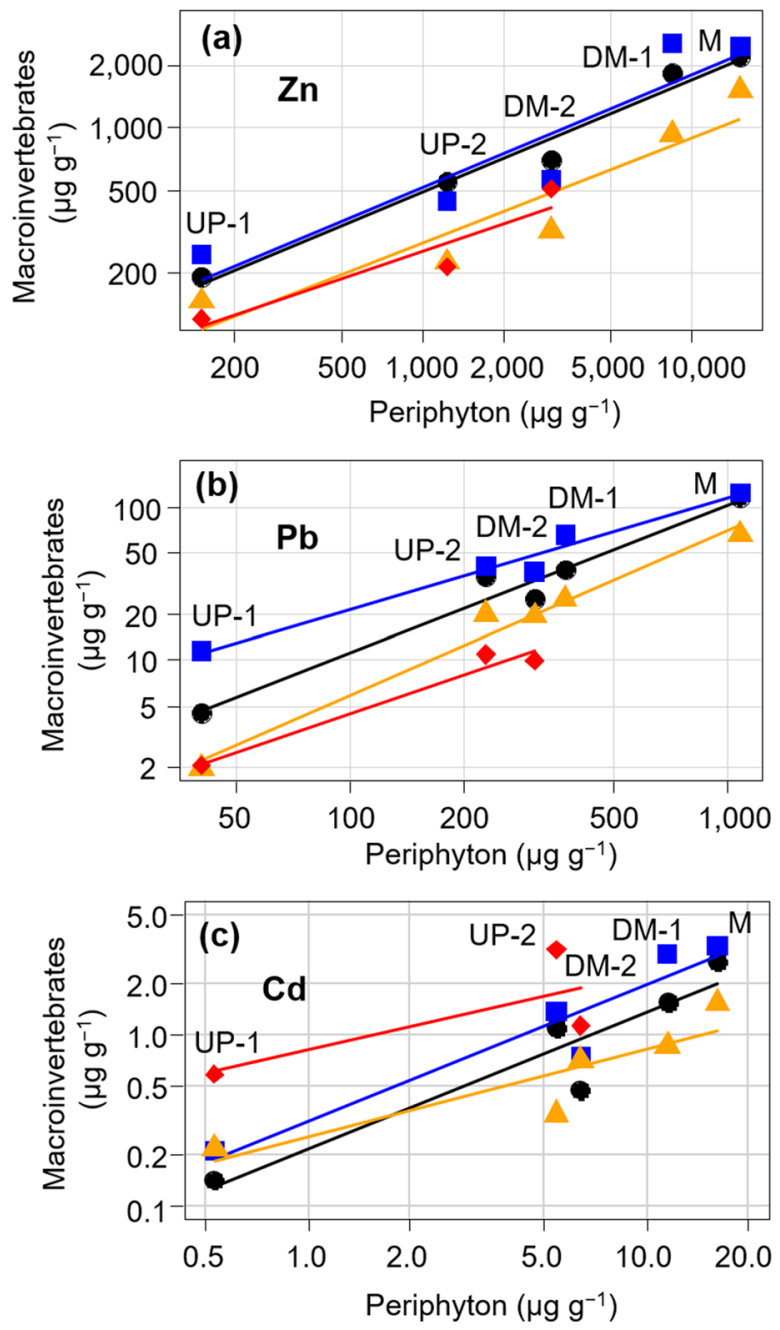

Fig. 4 Linear relationships of $\mathrm{Zn} \mathrm{(a),} \mathrm{Pb}(\mathbf{b})$ and $\mathrm{Cd}(\mathbf{c})$ concentrations between periphyton and four families of macroinvertebrates along the Osor stream. Snails of the family Lymnaeidae were not found at Mine (M) and Downstream 1 (DM-1). Linear functions are shown in Table S1. Note axes are on a log scale

Fish predation was not affected by metal pollution levels (Fig. 5a-d), i.e., the Reach $\times$ Treatment interaction term was not statistically significant (Table 3 ). Treatment effects on macroinvertebrates were statistically significant for Diptera (Fig. 5d). However, several macroinvertebrate responses approached statistical significance $(P<0.1)$, such as EPT taxa (Fig. 5a) and total macroinvertebrate density (Fig. 6). We also found that densities of snails and dipterans were much lower in Mine and Downstream 1 (Table 3; Fig. 5c, d), whereas total macroinvertebrate density was greatly reduced in Mine reach (Table 3; Fig. 6). EPT taxa also showed lower densities in Mine reach (Fig. 5a) although differences among reaches were marginally significant (Table 3 ). At the lower 
Table 3 Results of linear mixed models: effects of reach and treatment on density of benthic macroinvertebrates, chlorophyll- $a$ concentration and ash-free dry weight (AFDW) biomass

\begin{tabular}{|c|c|c|c|c|c|c|c|c|c|c|c|}
\hline & \multicolumn{3}{|l|}{ Reach } & \multicolumn{3}{|c|}{ Treatment } & \multicolumn{3}{|c|}{ Treatment $\times$ Reach } & \multicolumn{2}{|c|}{$\begin{array}{l}\text { Explained } \\
\text { variation }\end{array}$} \\
\hline & SS & $F$ value & $P$ & SS & $F$ value & $P$ & SS & $F$ value & $P$ & $R^{2} \mathrm{~m}$ & $R^{2} \mathrm{c}$ \\
\hline EPT & 14.64 & 3.12 & 0.066 & 11.20 & 9.55 & 0.091 & 7.13 & 1.52 & 0.216 & 0.44 & 0.58 \\
\hline $\mathrm{OCH}$ & 1.99 & 0.83 & 0.538 & 0.099 & 0.16 & 0.538 & 2.76 & 1.14 & 0.350 & 0.14 & 0.36 \\
\hline Diptera & 6.06 & 4.86 & 0.019 & 5.78 & 18.52 & $<0.001$ & 0.88 & 0.71 & 0.592 & 0.41 & 0.43 \\
\hline Snails & 1.46 & 10.93 & 0.001 & 0.03 & 0.95 & 0.431 & 0.20 & 1.51 & 0.219 & 0.51 & 0.62 \\
\hline $\begin{array}{c}\text { Total mac- } \\
\text { roinver- } \\
\text { tebrate } \\
\text { density }\end{array}$ & 205.32 & 7.33 & 0.005 & 72.81 & 10.40 & 0.084 & 27.58 & 0.99 & 0.427 & 0.55 & 0.68 \\
\hline Chlorophyll- $a$ & 0.027 & 3.09 & 0.024 & 0.066 & 30.80 & 0.031 & 0.01 & 0.83 & 0.516 & 0.52 & 0.54 \\
\hline AFDW & 0.24 & 1.73 & 0.221 & 3.55 & 103.61 & $<0.001$ & 0.06 & 0.44 & 0.776 & 0.64 & 0.67 \\
\hline
\end{tabular}

The degrees of freedom are 1 for Treatment, and 4 for Reach and the Reach $\times$ Treatment interaction term. Table shows variation explained by the fixed effects, i.e., 'Reach' and 'Treatment' $\left(R^{2} \mathrm{~m}\right)$; and by the sum of the fixed effects and the random effects, i.e., 'Time' and 'Replicate' $\left(R^{2} \mathrm{c}\right)$. EPT =Ephemeroptera-Plecoptera-Trichoptera orders; $\mathrm{OCH}=$ Odonata-Coleoptera-Hemiptera orders. Note: No hemipterans were found during the experiment. Variables were transformed using Box-Cox transformation. Significant results $(P<0.05)$ are in boldface trophic level, periphyton (chlorophyll- $a$ concentration and AFDW) showed a significant decrease in biomass in the presence of fish, regardless of metal pollution levels in the stream (Fig. 5e, f). Moreover, chlorophyll- $a$ concentration was significantly different among the reaches (Table 3), with Upstream 1 having a lower concentration of chlorophyll- $a$ compared to downstream reaches (Fig. 5e).

\section{Discussion}

The Osor stream showed a clear environmental stress gradient resulting from the interaction between metal pollution (direct metal inputs from the mine) and hydrological alteration (water diversion) (Bonet et al. 2013). We found Zn concentrations in water (maximum $\mathrm{Zn}$ value of $349 \mu \mathrm{g} \mathrm{L}^{-1}$ ) that largely exceed the chronic toxicity threshold $(120 \mu \mathrm{g}$ $\mathrm{Zn} \mathrm{L}^{-1}$ ) for freshwater biota based on the criteria developed by the US Environmental Protection Agency (EPA 2006). According to the 'biotic ligand model', which estimates bioavailability of metals based on hardness-based acute and/or chronic criteria (De Schamphelaere and Janssen 2004), the exposure to these $\mathrm{Zn}$ concentrations in slightly hard waters (15-50 mg Ca L ${ }^{-1}$ ) would likely have harmful effects on stream communities (Tlili et al. 2011; Corcoll et al. 2012; Bonet et al. 2013, 2014; Argudo et al. 2020). In addition to $\mathrm{Zn}$, we found high Mn concentrations in the stream waters of the Mine reach (143 $\mu \mathrm{g} \mathrm{Mn} \mathrm{L}^{-1}$ ) and high Fe concentrations in all reaches (range $=47-132 \mu \mathrm{g} \mathrm{Fe} \mathrm{L}^{-1}$ ), but no toxicity to biota is expected according to the EPA's water quality criterion and previous research (Cadmus et al. 2018).
Therefore, Zn was likely the primary chemical element driving the differences in toxicity observed among reaches (Atli et al. 2020).

Similar to other studies (e.g. Farag et al. 1998), we found that periphyton had the largest metal loads. Concentrations of $\mathrm{Zn}$ in periphyton increased gradually with dissolved concentrations in water, whereas this pattern was not observed for the other metals studied $(\mathrm{Cr}, \mathrm{Pb}$ and $\mathrm{Cd})$. These results suggest that, unlike other metals, Zn can be actively and rapidly adsorbed and/or taken up from water by periphyton (Kim et al. 2012). There were also significant relationships between the concentrations of various metals in periphyton and macroinvertebrates, reflecting the contaminant concentrations in water (e.g. see Santoro et al. 2009).

Metal loads ( $\mathrm{Zn}, \mathrm{Pb}$ and $\mathrm{Cd}$ ) differed among macroinvertebrate families of different feeding guilds, with lowest metal concentrations in dragonfly nymphs (Gomphidae), consistent with previous studies (Kiffney and Clements 1993; Goodyear and McNeill 1999). These studies also reported that shredders-scrapers that feed on periphytic algae tend to accumulate the largest metal concentrations, in agreement with the high metal concentrations found in detritivores stoneflies (Leuctridae). In our study, however, grazing snails (Radix sp.: Lymnaeidae) were extirpated from the most polluted reaches, possibly because this taxon is sensitive to high metal concentrations in the environment. Together, our results suggest that metals do not biomagnify between trophic levels of periphyton and macroinvertebrates, but they are bioavailable and do biotransfer, as noted previously in freshwaters (Farag et al. 1998; Goodyear and McNeill 1999). However, we acknowledge that the sample 

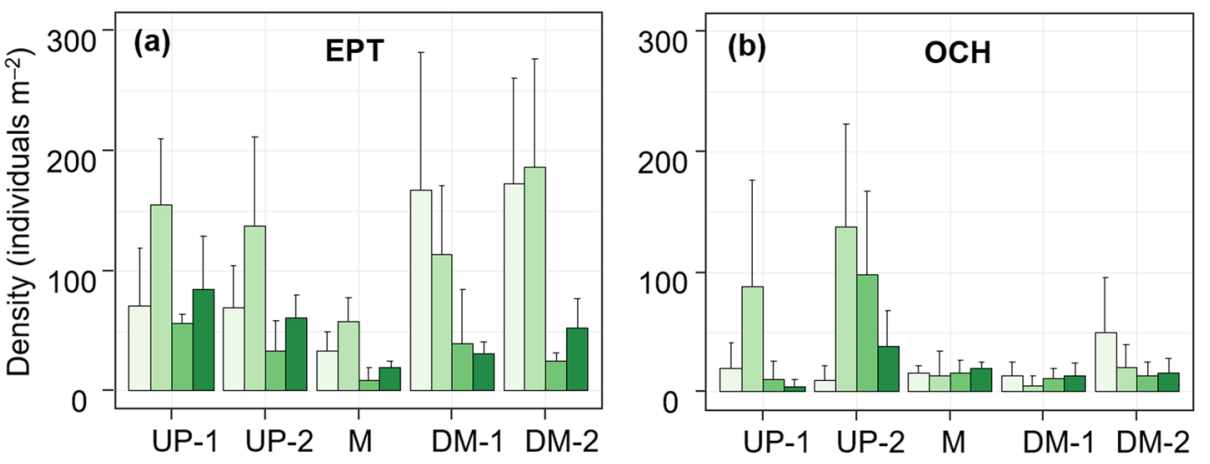

No fish (wk1)

No fish (wk2)

Fish (wk1)

Fish (wk2)
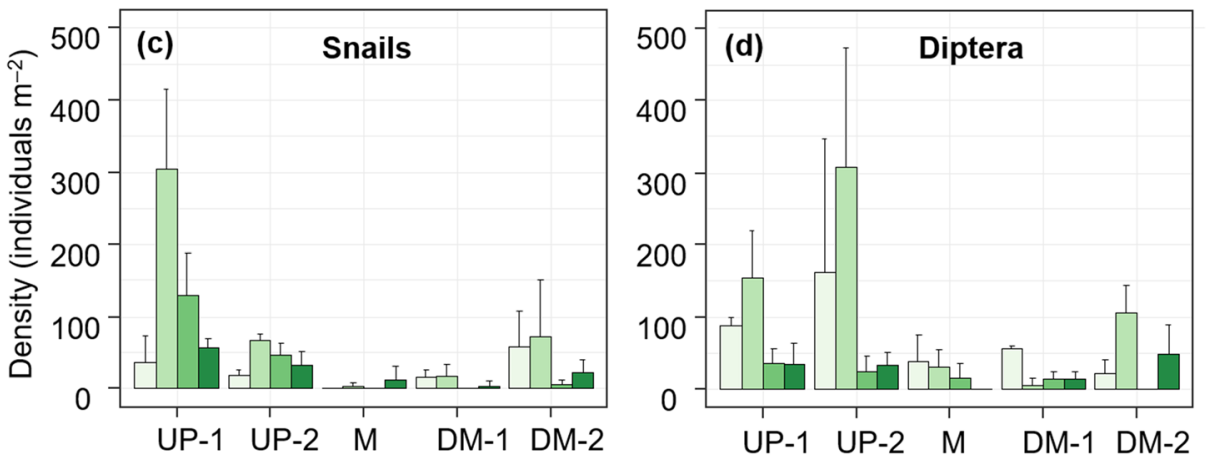

No fish (wk1)

No fish (wk2)

Fish (wk1)

Fish (wk2)
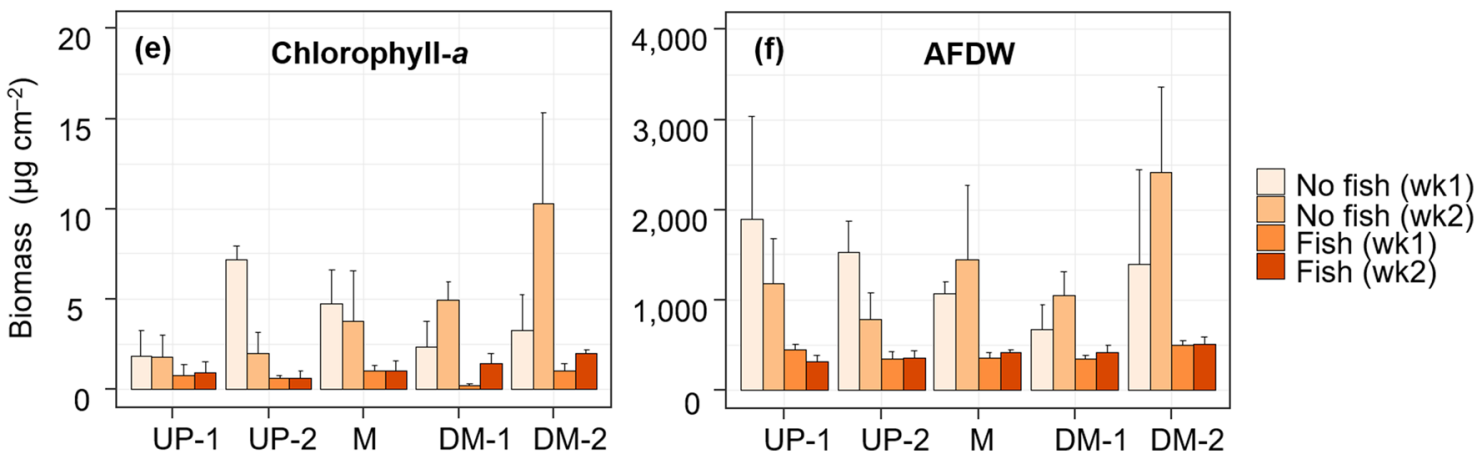

Fig. 5 Density of benthic macroinvertebrates, and both chlorophyll- $a$ concentration and ash-free dry weight (AFDW) biomass in response to the lack of fish ('No fish' treatment) and fish predation ('Fish'

treatment). The two treatments had a duration of 2 weeks and surveys were conducted at day 7 (wk1) and 14 (wk2) over the course of each treatment period. Bar plots show mean \pm standard deviation

size used for each family was small (only one sample per site) which diminishes the predictive power of linear regressions. Moreover, we were unable to exclude drifting larvae coming from unpolluted areas from the samples, which might have affected the overall concentrations of metals in these taxa.

Contrary to our expectations, periphyton biomass did not decrease due to metal exposure, as previously reported by other studies (Hill et al. 2000; Morin et al. 2007; Bonet et al. 2013). The lack of a response in periphyton across the metal pollution gradient may be related to shifts in abundance of dominant diatom species as a result of differential susceptibility to metals (Sabater et al. 2002). Moreover, the natural spatial and temporal variation on the responses of aquatic organisms to pollutants can complicate interpretation of field biomonitoring studies (Medley and Clements 1998; Clements et al. 2016). However, despite the invariant response of biomass, it is important to note that there was evidence of shifts in microbial community structure due to water stress and metal exposure (Argudo 2021), as reflected by the elevated toxic metal concentrations accumulated in periphyton.

Unlike periphyton biomass, density of grazing macroinvertebrates varied predictably across the metal pollution gradient, possibly because $\mathrm{Zn}$ concentrations in water and periphyton were sufficiently elevated to cause toxicity to this group of invertebrates (Clements and Rees 1997; Clements et al. 2000; Courtney and Clements 2002; Marqués et al. 


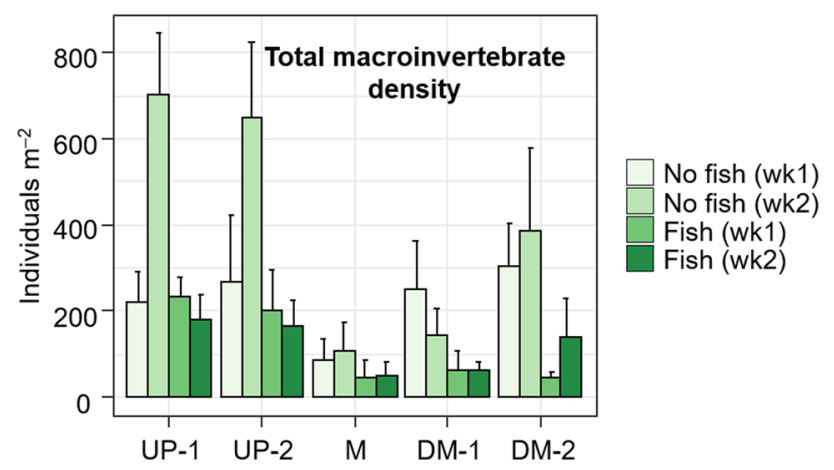

Fig. 6 Total density of benthic macroinvertebrates in response to the lack of fish ('No fish' treatment) and fish predation ('Fish' treatment). The two treatments had a duration of 2 weeks and surveys were conducted at day 7 (wk1) and 14 (wk2) over the course of each treatment period. Bar plots show mean \pm standard deviation

2003; Solà et al. 2004; Mebane et al. 2017). In addition to grazers, Clements et al. (2000) found strong effects of heavy metals on predators and to a lesser degree on shredders and collectors. This variation in the degree of response of the functional feeding groups to metals might change among streams due to different sensitives among species. Ultimately, we found that Leuctridae dominated macroinvertebrate communities at metal-polluted sites. This macroinvertebrate family has been found to be tolerant to environmental stressors in streams affected by pollution and acidification (Ledger and Hildrew 2005; Layer et al. 2013).

Results of the enclosure experiment showed that the topdown control of macroinvertebrates by fish was not contextdependent, i.e., none of the 'Treatment-Reach' interactions were significant (Table 3), which contrasts with the weaker predation effects of stoneflies on lower trophic level organisms in metal-polluted streams (Kiffney 1996; Clements 1999). Irrespective of metal pollution levels, fish predation effectively reduced the density of Diptera in cages, which is consistent with previous studies showing that Chironomids were the most abundant taxa in the gut contents of Barbus meridionalis (Mas-Martí et al. 2010; Rodríguez-Lozano et al. 2016b). However, this top predator has a generalized diet that includes primary consumers (e.g. mayflies) and other invertebrates as frequent prey sources (Mas-Martí et al. 2010; Rodríguez-Lozano et al. 2016b). As with Diptera, we found that total macroinvertebrate density and the density of EPT taxa tended to decrease in the presence of fish, but these responses were not significant because of relatively high variation. Nevertheless, there is compelling evidence that the top-down control of this predatory fish can change macroinvertebrate community composition and abundance (Rodríguez-Lozano et al. 2015, 2016a). Unfortunately, we cannot distinguish between consumption and prey turnover in cages. High immigration rates can overwhelm predation effects, while emigration can lower the risk of being eaten by the top predator (Clements 1999). A predator avoidance behavior has been observed, for instance, in mayflies during predator-inclusion experiments (e.g. Tikkanen et al. 1994).

Interestingly, periphyton was also predominantly controlled by Barbus meridionalis (up to 79\% decrease in biomass at the end of the experiment), thus suppressing any potential cascading effects along the stream. Predatory fishes commonly affect periphyton through trophic cascades (Dahl 1998; Moulton et al. 2010; Winkelmann et al. 2014). Thus, the reduced periphyton in the presence of fish can be attributed to two ecological processes associated with benthic foraging movements (Moore 2006): (1) predatory fishes can accidentally ingest periphytic algae and detritus while foraging benthic invertebrates (Mas-Martí et al. 2010); and (2) bottom-feeding taxa can decrease standing stocks of periphyton through severe perturbation of substrates (Power 1990b), the so-called 'bioturbation effect' (Fleeger et al. 2006). Similarly, Rodriguez-Lozano et al. (2015) pointed out that the lower sediment deposition caused by bioturbation of barbels, with a subsequent increase in light availability, led to increase periphyton net primary production. In addition, large predators are expected to generate greater impacts across multi-trophic levels than smaller predators like invertebrates (DeLong et al. 2015; Rodríguez-Lozano et al. 2015). Therefore, our findings could modify the general view of trophic relationships in freshwater ecosystems, given that they conflicted with some predictions from classic food web theory (Carpenter et al. 1985), which holds that each trophic level is related to the level above and below in a direct and negative way (see Fig. 1). We suggest that body size or functional traits (e.g., foraging behaviour), rather than feeding guild, are key determinants of the extent and magnitude of the influences of fishes in modifying stream food-web structure.

While the inclusion of fish in cages resulted in ubiquitous top-down effects on lower trophic levels, the fish removal revealed shifts in the strength of grazer-periphyton interactions because of heavy metal pollution. That is, chlorophyll- $a$ concentration (as a proxy for autotrophic community biomass) was significantly lower in the upper non-impacted reach (UP-1) likely due to higher grazing pressure (Feminella and Hawkins 1995), as reflected by the concomitant increase in density of snails and other aquatic taxa (e.g. mayflies). Conversely, these trophic interactions were not observed in downstream reaches with different levels of pollution, i.e., both chlorophyll- $a$ concentration and total periphyton biomass increased in the absence of fish. Fleeger et al. (2003) reviewed indirect toxicant effects in aquatic ecosystems across of 150 studies, and noted that the abundance of primary producers (i.e. benthic micro- and macroalgae) can be commonly altered in streams by contaminant-induced changes in grazing rates. This means that grazers can be 
selectively eliminated through mortality or that the grazing behavior can change by direct toxicant effects, thereby leading to indirect positive effects on periphytic algae. Our results are consistent with those findings, suggesting that periphytic algal biomass might benefit from lower grazing pressure in metal-polluted streams. In addition, the invariant response of ash-free dry mass to predator removal could be explained by the important fraction of debris, which grazers may not feed on, so that variation in chlorophyll- $a$ concentration is likely to be more closely linked to differences in grazing pressure (e.g. Ludlam and Magoulick 2010). Ultimately, it does not rule out the more developed riparian vegetation in the upper reach of the Osor stream decreased light availability for the primary producers, which can limit their growth (Bonet et al. 2013). Therefore, it is likely that periphyton biomass was controlled through both bottom-up (light availability) and top-down controls (grazing pressure) in the non-polluted sites.

\section{Conclusions}

The present study is the first to have assessed the responses of stream benthic communities to the presence or absence of a predatory fish (Barbus meridionalis) along a heavy-metal pollution gradient. We showed that different metal pollution levels did not influence the strength of the top-down control by fish on its most preferred prey (Chironomidae). Notably, it was also found that the bottom-dwelling fish can strongly reduce periphytic algae attached to cobbles primarily through bioturbation, regardless of metal pollution levels. On the other hand, indirect positive effects of toxicants on periphyton biomass were only observed in the absence of fish, showing that the strong top-down control by fish can overwhelm effects of heavy metal pollution on stream ecosystem structure. Finally, this study also showed that $\mathrm{Zn}$ exposure did not affect top-down processes, at least in the short-term (i.e. several weeks). Nonetheless, it may happen after chronic exposure if fish populations decrease. Therefore, our results suggest that the local extinction of riverine fishes could result in increased biomass of contaminated fluvial producers.

Documenting the complexity of trophic relationships in varying environments provides a fundamental basis for the understanding of the effects of human impacts on fluvial ecosystems (Clements and Rohr 2009; Segner et al. 2014). We concluded that trophic-level-based ecosystem approaches should be considered in future ecotoxicological studies to improve predictions of population or community changes at contaminated sites.
Supplementary Information The online version contains supplementary material available at https://doi.org/10.1007/s00027-022-00849-4.

Acknowledgements We are grateful to E. García-Berthou for providing statistical advice, C. Delgado and A. Barranquero for their field assistance and the Research Technical Services of the University of Girona for their help with the metal analyses. We would also like to thank two anonymous reviewers for comments on an earlier draft.

Funding Open Access funding provided thanks to the CRUE-CSIC agreement with Springer Nature. This research was supported by the Spanish Ministry of Science, Innovation and Universities (projects CGL2013-43822-R and CGL2016-80820-R, AEI/FEDER/EU) and the Government of Catalonia (ref. 2017 SGR 548 and CERCA Programme). F. Rubio-Gracia and M. Argudo benefitted from a predoctoral fellowship from the University of Girona (IFUdG2017) and the Agency for Management of University and Research Grants (AGAUR) of the Government of Catalonia (2016 FI-B 00284), respectively.

Availability of data and material The datasets generated and analysed during the current study are available from the corresponding author on reasonable request.

\section{Declarations}

Conflict of interest The authors have no conflict of interest to declare.

Ethical statement This study was conducted in compliance with the competent authority: the Autonomous Government of Catalonia (Generalitat). The project of animal experimentation (ref. 9673) was assessed by an animal experimentation committee (CEA). The status of the CEA is established in File CEA-OH/9673/1 of the Department of Territory and Sustainability. We also received the permit from the Agència Catalana de l'Aigua (ACA) to carry out the reported fieldwork. The study did not involve endangered or protected species. All experimental manipulations were conducted by trained personnel and field procedures caused the minimum possible adverse effects on aquatic wildlife.

Open Access This article is licensed under a Creative Commons Attribution 4.0 International License, which permits use, sharing, adaptation, distribution and reproduction in any medium or format, as long as you give appropriate credit to the original author(s) and the source, provide a link to the Creative Commons licence, and indicate if changes were made. The images or other third party material in this article are included in the article's Creative Commons licence, unless indicated otherwise in a credit line to the material. If material is not included in the article's Creative Commons licence and your intended use is not permitted by statutory regulation or exceeds the permitted use, you will need to obtain permission directly from the copyright holder. To view a copy of this licence, visit http://creativecommons.org/licenses/by/4.0/.

\section{References}

Alexander AC, Luis AT, Culp JM et al (2013) Can nutrients mask community responses to insecticide mixtures? Ecotoxicology 22:1085-1100. https://doi.org/10.1007/s10646-013-1096-3

Allan JD, Flecker AS (1993) Biodiversity conservation in running waters. Bioscience 43:32-43. https://doi.org/10.2307/1312104

Arenas-Sánchez A, Rico A, Vighi M (2016) Effects of water scarcity and chemical pollution in aquatic ecosystems: state of the art. 
Sci Total Environ 572:390-403. https://doi.org/10.1016/j.scito tenv.2016.07.211

Argudo M (2021) Microbial communities responses in fluvial biofilms under metal stressed scenarios. Dissertation, University of Girona

Argudo M, Gich F, Bonet B et al (2020) Responses of resident (DNA) and active (RNA) microbial communities in fluvial biofilms under different polluted scenarios. Chemosphere 242:125108. https://doi.org/10.1016/j.chemosphere.2019.125108

Atli G, Guasch H, Rubio-Gracia F et al (2020) Antioxidant system status in threatened native fish Barbus meridionalis from the Osor River (Iberian Peninsula): I. Characterization and II. In vitro $\mathrm{Zn}$ assays. Environ Toxicol Pharmacol 79:103428. https://doi.org/ 10.1016/j.etap.2020.103428

Bates D, Mächler M, Bolker BM, Walker SC (2015) Fitting linear mixed-effects models using lme4. J Stat Softw 67:1-48. https:// doi.org/10.18637/jss.v067.i01

Biggs BJF, Francoeur SN, Huryn AD et al (2000) Trophic cascades in streams: effects of nutrient enrichment on autotrophic and consumer benthic communities under two different fish predation regimes. Can J Fish Aquat Sci 57:1380-1394. https://doi.org/ 10.1139/cjfas-57-7-1380

Bonet B, Corcoll N, Acuňa V et al (2013) Seasonal changes in antioxidant enzyme activities of freshwater biofilms in a metal polluted Mediterranean stream. Sci Total Environ 444:1-10. https://doi. org/10.1016/j.scitotenv.2012.11.036

Bonet B, Corcoll N, Tlili A et al (2014) Antioxidant enzyme activities in biofilms as biomarker of $\mathrm{Zn}$ pollution in a natural system: an active bio-monitoring study. Ecotoxicol Environ Saf 103:82-90. https://doi.org/10.1016/j.ecoenv.2013.11.007

Bonnineau C, Artigas J, Chaumet B et al (2020) Role of biofilms in contaminant bioaccumulation and trophic transfer in aquatic ecosystems: current state of knowledge and future challenges. Reviews of environmental contamination and toxicology (continuation of residue reviews). Springer, New York. https://doi. org/10.1007/398_2019_39

Borer ET, Seabloom EW, Shurin JB et al (2005) What determines the strength of a trophic cascade? Ecology 86:528-537. https://doi. org/10.1890/03-0816

Box GE, Cox DR (1964) An analysis of transformations revisited, rebutted. J R Stat Soc Ser B 26:211-252. https://doi.org/10.1080/ 01621459.1982 .10477788

Brönmark C, Dahl J, Greenberg LA (1997) Complex trophic interactions in freshwater benthic food chains. In: Streit B, Städler T, Lively CM (eds) Evolutionary ecology of freshwater animals. EXS, vol 82. Birkhäuser, Basel, pp 55-88. https://doi.org/10. 1007/978-3-0348-8880-6 3

Brooks PR, Crowe TP (2018) Density and biotic interactions modify the combined effects of global and local stressors. Oikos 127:1746-1758. https://doi.org/10.1111/oik.04459

Bruder A, Frainer A, Rota T, Primicerio R (2019) The importance of ecological networks in multiple-stressor research and management. Front Environ Sci 7:1-7. https://doi.org/10.3389/fenvs. 2019.00059

Cadmus P, Guasch H, Herdrich AT et al (2018) Structural and functional responses of periphyton and macroinvertebrate communities to ferric $\mathrm{Fe}, \mathrm{Cu}$, and $\mathrm{Zn}$ in stream mesocosms. Environ Toxicol Chem 37:1320-1329. https://doi.org/10.1002/etc.4070

Carpenter SR, Kitchell JF, Hodgson JR (1985) Cascading trophic interactions and lake productivity. Bioscience 35:634-639. https:// doi.org/10.2307/1309989

Cheng BS, Grosholz ED (2016) Environmental stress mediates trophic cascade strength and resistance to invasion. Ecosphere 7:e01247. https://doi.org/10.1002/ecs2.1247
Clements WH (1999) Metal tolerance and predator-prey interactions in benthic macroinvertebrate stream communities. Ecol Appl 9:1073-1084. https://doi.org/10.2307/2641352

Clements WH, Rees DE (1997) Effects of heavy metals on prey abundance, feeding habits, and metal uptake of brown trout in the Arkansas River, Colorado. Trans Am Fish Soc 126:774-785. https://doi.org/10.1577/1548-8659(1997)126\%3c0774:eohmop\% 3e2.3.co;2

Clements WH, Rohr JR (2009) Community responses to contaminants: using basic ecological principles to predict ecotoxicological effects. Environ Toxicol Chem 28:1789-1800. https://doi.org/ 10.1897/09-140.1

Clements WH, Carlisle DM, Lazorchak JM, Johnson PC (2000) Heavy metals structure benthic communities in Colorado mountain streams. Ecol Appl 10:626-638. https://doi.org/10.1890/10510761(2000)010[0626:HMSBCI]2.0.CO;2

Clements WH, Kashian DR, Kiffney PM, Zuellig RE (2016) Perspectives on the context-dependency of stream community responses to contaminants. Freshw Biol 61:2162-2170. https://doi.org/10. 1111/fwb.12599

Corcoll N, Bonet B, Morin S et al (2012) The effect of metals on photosynthesis processes and diatom metrics of biofilm from a metal-contaminated river: a translocation experiment. Ecol Indic 18:620-631. https://doi.org/10.1016/j.ecolind.2012.01.026

Courtney LA, Clements WH (2002) Assessing the influence of water and substratum quality on benthic macroinvertebrate communities in a metal-polluted stream: an experimental approach. Freshw Biol 47:1766-1778. https://doi.org/10.1046/j.1365-2427. 2002.00896.x

Dahl J (1998) Effects of a benthivorous and a drift-feeding fish on a benthic stream assemblage. Oecologia 116:426-432. https://doi. org/10.1007/s004420050606

De Schamphelaere KAC, Janssen CR (2004) Bioavailability and chronic toxicity of zinc to juvenile rainbow trout (Oncorhynchus mykiss): comparison with other fish species and development of a biotic ligand model. Environ Sci Technol 38:6201-6209. https:// doi.org/10.1021/es049720m

DeLong JP, Gilbert B, Shurin JB et al (2015) The body size dependence of trophic cascades. Am Nat 185:354-366. https://doi.org/ $10.1086 / 679735$

Environmental Protection Agency of United States, EPA (2006) National recommended water quality criteria table: poster and brochure. http://water.epa.gov/type/rsl/

Farag AM, Woodward DF, Goldstein JN et al (1998) Concentrations of metals associated with mining waste in sediments, biofilm, benthic macroinvertebrates, and fish from the Coeur d'Alene River Basin, Idaho. Arch Environ Contam Toxicol 34:119-127. https:// doi.org/10.1007/s002449900295

Feminella JW, Hawkins CP (1995) Interactions between stream herbivores and periphyton: a quantitative analysis of past experiments. J North Am Benthol Soc 14:465-509. https://doi.org/10.2307/ 1467536

Flecker AS, Townsend CR (1994) Community-wide consequences of trout introduction in New Zealand streams. Ecol Appl 4:798 807. https://doi.org/10.2307/1942009

Fleeger JW, Carman KR, Nisbet RM (2003) Indirect effects of contaminants in aquatic ecosystems. Sci Total Environ 317:207-233. https://doi.org/10.1016/S0048-9697(03)00141-4

Fleeger JW, Tita G, Carman KR et al (2006) Does bioturbation by a benthic fish modify the effects of sediment contamination on saltmarsh benthic microalgae and meiofauna? J Exp Mar Bio Ecol 330:180-194. https://doi.org/10.1016/j.jembe.2005.12.026

Gartzia De Bikuña B, López E, Leonardo JM et al (2015) Reduction of sampling effort assessing macroinvertebrate assemblages for biomonitoring of rivers. Knowl Manag Aquat Ecosyst 416:08. https://doi.org/10.1051/kmae/2015004 
Geist J (2011) Integrative freshwater ecology and biodiversity conservation. Ecol Indic 11:1507-1516. https://doi.org/10.1016/j. ecolind.2011.04.002

Goodyear KL, McNeill S (1999) Bioaccumulation of heavy metals by aquatic macro-invertebrates of different feeding guilds: a review. Sci Total Environ 229:1-19. https://doi.org/10.1016/ S0048-9697(99)00051-0

Guasch H, Serra A, Corcoll N et al (2009) Metal ecotoxicology in fluvial biofilms: potential influence of water scarcity. In: Sabater S, Barceló D (eds) Water scarcity in the Mediterranean the handbook of environmental chemistry, vol 8. Springer. Berlin, Heidelberg, pp 41-53. https://doi.org/10.1007/698_2009_25

Guasch H, Atli G, Bonet B et al (2010) Discharge and the response of biofilms to metal exposure in Mediterranean rivers. Hydrobiologia 657:143-157. https://doi.org/10.1007/s10750-010-0116-z

Guasch H, Artigas J, Bonet B et al (2016) The use of biofilms to assess the effects of chemicals on freshwater ecosystems. In: Romaní AM, Guasch H, Balaguer MD (eds) Aquatic biofilms: ecology, water quality and wastewater treatment. Caister Academic Press, Norfolk, pp 125-144. https://doi.org/10.21775/9781910190173

Hill BH, Willingham WT, Parrish LP, McFarland BH (2000) Periphyton community responses to elevated metal concentrations in a Rocky Mountain stream. Hydrobiologia 428:161-169. https:// doi.org/10.1023/A:1004028318542

Holomuzki JR, Feminella JW, Power ME (2010) Biotic interactions in freshwater benthic habitats. J North Am Benthol Soc 29:220244. https://doi.org/10.1899/08-044.1

Iwasaki Y, Kagaya T, Miyamoto KI, Matsuda H (2009) Effects of heavy metals on riverine benthic macroinvertebrate assemblages with reference to potential food availability for drift-feeding fishes. Environ Toxicol Chem 28:354-363. https://doi.org/10.1897/ 08-200.1

Jeffrey SW, Humphrey GF (1975) New spectrophotometric equations for determining chlorophylls $a, b, c_{1}$ and $c_{2}$ in higher plants, algae and natural phytoplankton. Biochem Physiol Pflanz 167:191194. https://doi.org/10.1016/S0015-3796(17)30778-3

Kalogianni E, Vourka A, Karaouzas I et al (2017) Combined effects of water stress and pollution on macroinvertebrate and fish assemblages in a Mediterranean intermittent river. Sci Total Environ 603-604:639-650. https://doi.org/10.1016/j.scitotenv.2017.06. 078

Karaouzas I, Smeti E, Vourka A et al (2018) Assessing the ecological effects of water stress and pollution in a temporary riverimplications for water management. Sci Total Environ 618:15911604. https://doi.org/10.1016/j.scitotenv.2017.09.323

Kiffney PM (1996) Main and interactive effects of invertebrate density, predation, and metals on a Rocky Mountain stream macroinvertebrate community. Can J Fish Aquat Sci 53:1595-1601. https:// doi.org/10.1139/cjfas-53-7-1595

Kiffney PM, Clements WH (1993) Bioaccumulation of heavy metals by benthic invertebrates at the Arkansas River, Colorado. Environ Toxicol Chem 12:1507-1517. https://doi.org/10.1002/ etc. 5620120818

Kim KS, Funk DH, Buchwalter DB (2012) Dietary (periphyton) and aqueous $\mathrm{Zn}$ bioaccumulation dynamics in the mayfly Centroptilum triangulifer. Ecotoxicology 21:2288-2296. https://doi.org/ 10.1007/s10646-012-0985-1

Klemmer AJ, Richardson JS (2013) Quantitative gradient of subsidies reveals a threshold in community-level trophic cascades. Ecology 94:1920-1926. https://doi.org/10.1890/12-1444.1

Konishi M, Nakano S, Iwata T (2001) Trophic cascading effects of predatory fish on leaf litter processing in a Japanese stream. Ecol Res 16:415-422. https://doi.org/10.1046/j.1440-1703.2001. 00406.x

Korpinen S, Jormalainen V, Honkanen T (2007) Bottom-up and cascading top-down control of macroalgae along a depth gradient.
J Exp Mar Bio Ecol 343:52-63. https://doi.org/10.1016/j.jembe. 2006.11.012

Kotalik CJ, Clements WH (2019) Stream mesocosm experiments show significant differences in sensitivity of larval and emerging adults to metals. Environ Sci Technol 53:8362-8370. https://doi.org/10. 1021/acs.est.9b00883

Kuznetsova A, Brockhoff PB, Christensen RHB (2017) lmerTest package: tests in linear mixed effects models. J Stat Softw 82:1-26. https://doi.org/10.18637/jss.v082.i13

Layer K, Riede JO, Hildrew AG, Woodward G (2010) Food Web structure and stability in 20 streams across a wide $\mathrm{pH}$ gradient. In: Woodward G (ed) Advances in ecological research, vol 42. Academic Press, London, pp 265-299. https://doi.org/10.1016/ B978-0-12-381363-3.00005-8

Layer K, Hildrew AG, Woodward G (2013) Grazing and detritivory in 20 stream food webs across a broad $\mathrm{pH}$ gradient. Oecologia 171:459-471. https://doi.org/10.1007/s00442-012-2421-x

Ledger ME, Hildrew AG (2005) The ecology of acidification and recovery: changes in herbivore-algal food web linkages across a stream pH gradient. Environ Pollut 137:103-118. https://doi. org/10.1016/j.envpol.2004.12.024

Leroux SJ, Loreau M (2008) Subsidy hypothesis and strength of trophic cascades across ecosystems. Ecol Lett 11:1147-1156. https://doi. org/10.1111/j.1461-0248.2008.01235.x

Ludlam JP, Magoulick DD (2010) Environmental conditions and biotic interactions influence ecosystem structure and function in a drying stream. Hydrobiologia 644:127-137. https://doi. org/10.1007/s10750-010-0102-5

Maret TR, Cain DJ, MacCoy DE, Short TM (2003) Response of benthic invertebrate assemblages to metal exposure and bioaccumulation associated with hard-rock mining in northwestern streams, USA. J North Am Benthol Soc 22:598-620. https:// doi.org/10.2307/1468356

Marqués MJ, Martínez-Conde E, Rovira JV (2003) Effects of zinc and lead mining on the benthic macroinvertebrates of a fluvial ecosystem. Water Air Soil Pollut 148:363-388. https://doi.org/ 10.1023/A:1025411932330

Mas-Martí E, García-Berthou E, Sabater S et al (2010) Comparing fish assemblages and trophic ecology of permanent and intermittent reaches in a Mediterranean stream. Hydrobiologia 657:167-180. https://doi.org/10.1007/s10750-010-0292-x

McAfee D, Bishop MJ (2019) The mechanisms by which oysters facilitate invertebrates vary across environmental gradients. Oecologia 189:1095-1106. https://doi.org/10.1007/ s00442-019-04359-3

Mebane CA, Schmidt TS, Balistrieri LS (2017) Larval aquatic insect responses to cadmium and zinc in experimental streams. Environ Toxicol Chem 36:749-762. https://doi.org/10.1002/etc. 3599

Medley CN, Clements WH (1998) Responses of diatom communities to heavy metals in streams: the influence of longitudinal variation. Ecol Appl 8:631-644. https://doi.org/10.1890/10510761(1998)008[0631:RODCTH]2.0.CO;2

Menge BA, Sutherland JP (1987) Community regulation: variation in disturbance, competition, and predation in relation to environmental stress and recruitment. Am Nat 130:730-757. https:// doi.org/10.1086/284741

Moore JW (2006) Animal ecosystem engineers in streams. Bioscience 56:237-246. https://doi.org/10.1641/0006-3568(2006)056[0237: AEEIS]2.0.CO;2

Morin S, Vivas-Nogues M, Duong TT et al (2007) Dynamics of benthic diatom colonization in a cadmium/zinc-polluted river (RiouMort, France). Fundam Appl Limnol 168:179-187. https://doi. org/10.1127/1863-9135/2007/0168-0179

Morin S, Duong TT, Dabrin A et al (2008) Long-term survey of heavymetal pollution, biofilm contamination and diatom community 
structure in the Riou Mort watershed, South-West France. Environ Pollut 151:532-542. https://doi.org/10.1016/j.envpol.2007. 04.023

Moulton TP, de Souza ML, Silveira RML, Krsulović FAM (2004) Effects of ephemeropterans and shrimps on periphyton and sediments in a coastal stream (Atlantic forest, Rio de Janeiro, Brazil). J North Am Benthol Soc 23:868-881. https://doi.org/10.1899/ 0887-3593(2004)023\%3c0868:EOEASO\%3e2.0.CO;2

Moulton TP, Souza ML, Silveira RML et al (2010) Patterns of periphyton are determined by cascading trophic relationships in two neotropical streams. Mar Freshw Res 61:57-64. https://doi.org/ 10.1071/MF08326

Murphy J, Riley JP (1962) A modified single solution method for the determination of phosphate in natural waters. Anal Chim Acta 27:31-36. https://doi.org/10.1016/S0003-2670(00)88444-5

Nakagawa S, Schielzeth H (2013) A general and simple method for obtaining $R^{2}$ from generalized linear mixed-effects models. Methods Ecol Evol 4:133-142. https://doi.org/10.1111/j.2041210x.2012.00261.x

Ormerod SJ, Dobson M, Hildrew AG, Townsend CR (2010) Multiple stressors in freshwater ecosystems. Freshw Biol 55:1-4. https:// doi.org/10.1111/j.1365-2427.2009.02395.x

Petrovic M, Ginebreda A, Acuña V et al (2011) Combined scenarios of chemical and ecological quality under water scarcity in Mediterranean rivers. TrAC Trends Anal Chem 30:1269-1278. https:// doi.org/10.1016/j.trac.2011.04.012

Polis GA, Sears ALW, Huxel GR et al (2000) When is a trophic cascade a trophic cascade? Trends Ecol Evol 15:473-475. https://doi.org/ 10.1016/S0169-5347(00)01971-6

Ponsatí L, Corcoll N, Petrović M et al (2016) Multiple-stressor effects on river biofilms under different hydrological conditions. Freshw Biol 61:2102-2115. https://doi.org/10.1111/fwb.12764

Power ME (1990a) Effects of fish in river food webs. Science 250:811814. https://doi.org/10.1126/science.250.4982.811

Power ME (1990b) Resource enhancement by indirect effects of grazers: armored catfish, algae, and sediment. Ecology 71:897-904. https://doi.org/10.2307/1937361

Power ME (1992) Habitat heterogeneity and the functional signifiance of fish in river food webs. Ecology 73:1675-1688. https://doi. org/10.2307/1940019

R Development Core Team (2018) R: a language and environment for statistical computing. Vienna, Austria. http://www.R-project.org/

Reardon J, Foreman JA, Searcy RL (1966) New reactants for the colorimetric determination of ammonia. Clin Chim Acta 14:403-405. https://doi.org/10.1016/0009-8981(66)90120-3

Ripple WJ, Estes JA, Schmitz OJ et al (2016) What is a trophic cascade? Trends Ecol Evol 31:842-849. https://doi.org/10.1016/j. tree.2016.08.010

Ritchie EG, Johnson CN (2009) Predator interactions, mesopredator release and biodiversity conservation. Ecol Lett 12:982-998. https://doi.org/10.1111/j.1461-0248.2009.01347.x

Rodrigues ACM, Machado AL, Bordalo MD et al (2018) Invasive species mediate insecticide effects on community and ecosystem functioning. Environ Sci Technol 52:4889-4900. https://doi.org/ 10.1021/acs.est.8b00193

Rodríguez-Lozano P, Verkaik I, Rieradevall M, Prat N (2015) Small but powerful: top predator local extinction affects ecosystem structure and function in an intermittent stream. PLoS ONE 10:e0117630. https://doi.org/10.1371/journal.pone.0117630

Rodríguez-Lozano P, Rieradevall M, Prat N (2016a) Top predator absence enhances leaf breakdown in an intermittent stream. Sci Total Environ 572:1123-1131. https://doi.org/10.1016/j.scito tenv.2016.08.021

Rodríguez-Lozano P, Verkaik I, Maceda-Veiga A et al (2016b) A trait-based approach reveals the feeding selectivity of a small endangered Mediterranean fish. Ecol Evol 6:3299-3310. https:// doi.org/10.1002/ece3.2117

Rosenfeld J (2000) Effects of fish predation in erosional and depositional habitats in a temperate stream. Can J Fish Aquat Sci 57:1369-1379. https://doi.org/10.1139/cjfas-57-7-1369

Rubio-Gracia F, Almeida D, Bonet B et al (2017) Combined effects of hydrologic alteration and cyprinid fish in mediating biogeochemical processes in a Mediterranean stream. Sci Total Environ 601-602:1217-1225. https://doi.org/10.1016/j.scitotenv.2017.05. 287

Saaristo M, Brodin T, Balshine S et al (2018) Direct and indirect effects of chemical contaminants on the behaviour, ecology and evolution of wildlife. Proc R Soc B 285:20181297. https://doi.org/10. 1098/rspb.2018.1297

Sabater S, Navarro E, Guasch H (2002) Effects of copper on algal communities at different current velocities. J Appl Phycol 14:391398. https://doi.org/10.1023/A:1022142227394

Sabater S, Barceló D, De Castro-Català N et al (2016) Shared effects of organic microcontaminants and environmental stressors on biofilms and invertebrates in impaired rivers. Environ Pollut 210:303-314. https://doi.org/10.1016/j.envpol.2016.01.037

Santoro A, Blo G, Mastrolitti S, Fagioli F (2009) Bioaccumulation of heavy metals by aquatic macroinvertebrates along the Basento River in the South of Italy. Water Air Soil Pollut 201:19-31. https://doi.org/10.1007/s11270-008-9923-5

Schmitz OJ, Krivan V, Ovadia O (2004) Trophic cascades: the primacy of trait-mediated indirect interactions. Ecol Lett 7:153-163. https://doi.org/10.1111/j.1461-0248.2003.00560.x

Segner H, Schmitt-Jansen M, Sabater S (2014) Assessing the impact of multiple stressors on aquatic biota: the receptor's side matters. Environ Sci Technol 48:7690-7696. https://doi.org/10.1021/ es405082t

Smolders AJP, Lock RAC, Van der Velde G et al (2003) Effects of mining activities on heavy metal concentrations in water, sediment, and macroinvertebrates in different reaches of the Pilcomayo River, South America. Arch Environ Contam Toxicol 44:314 323. https://doi.org/10.1007/s00244-002-2042-1

Solà C, Burgos M, Plazuelo Á et al (2004) Heavy metal bioaccumulation and macroinvertebrate community changes in a Mediterranean stream affected by acid mine drainage and an accidental spill (Guadiamar River, SW Spain). Sci Total Environ 333:109_ 126. https://doi.org/10.1016/j.scitotenv.2004.05.011

Steinman AD, Lamberti GA, Leavitt PR (2007) Biomass and pigments of benthic algae. In: Hauer FR, Lamberti GA (eds) Methods in stream ecology, 2nd edn. Academic Press, London, pp 357-379. https://doi.org/10.1016/B978-012332908-0.50024-3

Strong DR (1992) Are trophic cascades all wet? Differentiation and donor-control in speciose ecosystems. Ecology 73:747-754. https://doi.org/10.2307/1940154

Tachet H, Richoux P, Bournard M, Usseglio-Polatera P (2000) Invertébrés d'eau douce: systématique, biologie, écologie. CNRS éditions, Paris

Tikkanen P, Muotka T, Huhta A (1994) Predator detection and avoidance by lotic mayfly nymphs of different size. Oecologia 99:252259. https://doi.org/10.1007/BF00627737

Tlili A, Corcoll N, Bonet B et al (2011) In situ spatio-temporal changes in pollution-induced community tolerance to zinc in autotrophic and heterotrophic biofilm communities. Ecotoxicology 20:18231839. https://doi.org/10.1007/s10646-011-0721-2

Winkelmann C, Schneider J, Mewes D et al (2014) Top-down and bottom-up control of periphyton by benthivorous fish and light supply in two streams. Freshw Biol 59:803-818. https://doi.org/ 10.1111/fwb. 12305

Wootton JT (1994) The nature and consequences of indirect effects in ecological communities. Annu Rev Ecol Syst 25:443-466. https://doi.org/10.1146/annurev.es.25.110194.002303 
Publisher's Note Springer Nature remains neutral with regard to jurisdictional claims in published maps and institutional affiliations. 